\title{
Equity, Diversity and Internationalization in Indigenous and Intercultural Higher Education in Latin America
}

\author{
By Sylvie Didou Aupetit*
}

\begin{abstract}
A central innovation in Latin America with regard to higher education consisted in the opening of institutions and programs of higher education aimed at vulnerable populations due to insufficient income, restricted access to welfare services and/or ethnic origin. In this paper, we will analyze questions raised by the education of young native people by intercultural, indigenous and conventional institutions and the role of international organisms in their promotion at regional level. We will examine programs aimed at the redistribution of opportunities and the biases involved not only in their establishment and consolidation but also in their interaction with local, national and international organizations located in the field of indigenous higher education. After analyzing the context and the components of relevant initiatives, we will present some results of interviews conducted with some 80 indigenous graduates in Mexico in order to identify the issues linked, from the perspective of the beneficiaries, with their training paths, their professional and existential trajectories as well as their ethnic commitments.
\end{abstract}

Keywords: indigenous higher education, indigenous and intercultural institutions, public policies

\section{Introduction}

In Latin America, the decade beginning in 2000 was characterized by the creation of institutions and programs of higher education aimed at indigenous populations. They were justified by the fact that, in Latin America, these populations usually combined the lack of education with deficits in average access to all services of social wellbeing. They were also a result of increasing mobilizations of ethnic associations and a response to the emergence of indigenous peoples as political actors in the nineties (Bengoa, 2003, p. 8). They demanded that young indigenous persons have access to higher education in greater proportion, because of the urgency of training indigenous leaders and highly skilled human resources able to negotiate on equal terms with representatives of dominant groups with regard to their fundamental rights (territorial, cultural and human) and the occupation of political spaces. ${ }^{1}$

The design and implementation of these institutions and programs, in turn,

\footnotetext{
${ }^{*}$ Researcher, Center for Research and Advanced Studies, Mexico.

${ }^{1}$ Dietz and Mateos point to the shaping of "a new generation of indigenous and/or mestizo intelligentsia, widely learned and increasingly focused on dialogue with actors outside their communities that would allow for the establishment of novel relationships of co-management, mutual negotiation and local feedback" (Dietz and Mateos, 2011, p. 112).
} 
resulted from alliances between four main actors: educational, governmental, ethnic type associations and international organizations. The agreements between these different promoters of higher education for indigenous peoples led to a variety of measures that, depending on the degree of consensus and dissension between them, focused more attention on their own respective purposes than on those they had settled on. Outstanding among these were improving the effectiveness of the educational system, responsibility toward vulnerable populations, conservation of cultural diversity and reinforcement of social cohesion in profoundly unequal societies.

In this paper, we will review the solutions that were adopted to promote greater equality in the enrollment and graduation levels of young indigenous people and lessen the discrimination that affects them in the higher education system. We will reflect on the challenges that their attention poses for the institutional organization and higher education system. We will analyze how internationalization is a mechanism that helps to respond to certain issues faced by ethnic-based programs and institutions, showing the contributions of international organizations to the field and discussing certain criticisms, mainly from indigenous intellectuals, generated by their predominance in this specific area.

Our main hypothesis is that ethnic higher education is a diversified field under tension because of the various objectives and values that it brings together. This variety has an impact on reaching agreements, defining goals and experimenting with innovative educational projects. Taking it into consideration, we will use the notion of "conflict" as a sociological phenomenon linked to a specific period and context. Our starting point will be the idea that ethnic-based programs and institutions represent an arena in dispute because of the confrontation between the divergent interests of the different groups involved in their design, coordination and operation. Consequently, in using the notion of conflict, we will not refer to the ideological constructs that attribute to indigenous peoples a rebellious and subversive nature and make them responsible for the outbreak of crisis ${ }^{1}$. We will attempt to "understand its meaning and to comprehend from what perspective, why and for whom social processes are conflictive" (Bello, 2004, p. 37). We will dissolve the knots of the conflicts (conceptual, organizational and political) that trouble higher education projects for indigenous peoples. We will define them as the product of decisions adopted by the four main groups involved in indigenous higher education. Those decisions are resulting of decisional mindsets defined by the garbage can model (Cohen, March \& Olsen, 1972), that is, choices made in the absence of consensus.

\footnotetext{
1 "The indigenous conflict would be, in that sense, the result of the action of the indigenous subject who is rooted and obstinate in tradition and resistant to receiving the "offerings" of modernity. From another perspective, indigenous peoples would be conflictual because they pressure society and the political system with age-old demands difficult to achieve. Finally, the conflicting nature of indigenous movements may be found in the search to be different, something that would contradict modern logic if we consider that the emergence of the national state has had as one of its aims the search for equality, despite its being abstract and universal." (Bello, 2004, p. 36).
} 


\section{The Diversification of Ethnic Higher Education in Latin America}

For quite some time, Protestant churches (the Moravian Church in Nicaragua, the Southern Methodist Church of the United States through the Summer Language Institute since the 1940s in Mexico, Peru, Guatemala, Ecuador, Bolivia, Brazil, Colombia, Honduras, Surinam, Panama, Chile), Catholic orders, such as the Jesuits and Lasallians, and ethnic-type associations, sometimes associated with political parties, carried out educational actions aimed at indigenous populations in Latin America. But it was at the end of the 1990s when far-reaching initiatives of higher education appeared, changing the traditional landscape. Their establishment brought together government agencies, civil associations, higher education institutions (HEI) and international organizations, each of them with different purposes and resources.

Claim from native associations for access to higher education and/or to develop theirs owns models of ethnic higher education were formulated and received by national societies with greater or less hostility depending on the country. They were framed in constitutional and legal changes regarding the rights of indigenous peoples and were based on the evidence that, in the entire region, their rates of enrollment in post-mandatory education were less than the average (Zapata, 2009). They questioned governments, mainly those in charge of processes of democratic transition or after the end of violence (for Guatemala, Chojoj Mux, 2012), and HEIs, confronted with high dropout rates due to the social, economic and cultural diversification of mass enrollment. They struck a chord in international organizations (UNESCO, IESALCUNESCO), foundations (Ford, Fulbright, Kellogg), international banks (World Bank, Inter-American Development Bank), as well as in bilateral cooperation agencies (Norway's NORAD, Spain's AECID, Germany's GZT), interested in deactivating the intergenerational transmission of poverty, strengthening capabilities and reducing inequality (López, Moya \& Hamel, 2009). They brought together a total of four main actors, who, based on their agendas and internal collaborative agreements, implemented programs alternately aimed at promoting equity and social justice, preserving cultural diversity and empowering vulnerable groups. These accords, formalized through cooperative agreements, loans, non-refundable credits or donations, were arrangements that allowed the interested parties to combine resources and legitimize initiatives that, in principle, were not always perceived as relevant in the local environments or even in broad university sectors. The need to overcome everyday racism (Essed, 2005) and to lessen resistance against affirmative action led promoters of indigenous higher education to combine their expertise, financial resources and prestige not only to impulse innovation but also to justify it.

Alliances between international organizations, governments, universities, cooperative agencies or ethnic associations and any of the previously mentioned organizations were variable, in terms of dialogue, participation and control. Their profiles differed depending on the framework of their 
negotiations and involved difficult external and internal processes of legitimization (see the legislative and public opinion debates in Brazil regarding ethnic quotas for the enrollment of afro-descendants in federal universities since 2004, for instance). The alliances involved reaching a minimum basis of convergence between promoters, operators, mediators and indigenous peoples about approaches and targeted groups. But the fragility of those consensuses between distinct partners who were not in the position of peers, but rather superiors and inferiors, with different interests, caused instability in the policy or program execution processes and reduce its effectiveness.

In short, indigenous higher education is a conflictual field because of its social contexts, its historical relationships of power between the stakeholders and external interested parties and because it represents an area of contact between a broad spectrums of heterogeneous players that sometimes find themselves in opposition, in regard with their own commitments, mechanisms and expected outcomes. The agreements are thus basic and always susceptible of being questioned from within (by one or several of the initial supporting groups, by professors who criticize the guardianship of indigenous students and by non-native students who see support of their indigenous classmates as favoritism). The complications for achieving and carrying out solid, reasoned agreements, instead of opportunistic ones, explain, paradoxically, the preponderance given to the participation of indigenous actors in the rhetoric of non-indigenous actors. In the case of the latter, it also explains their complaints regarding the lack of autonomy in making decisions that influence programs for those who are the recipients.

Thus, the instability of networks ant the rift between bottom-up initiatives and those that are hierarchical and centralized. Thus, the conflicting values of those counterparts who defend political approaches and those who try to attain student achievements. Hence, the biases between those who try to structure alternative projects of higher education, based on recognition and incorporation of indigenous knowledge in the curriculum and those who resort to equity by improving the completion rates of students with learning difficulties through pedagogical intervention and tutorial assistance schemes. Consequently, the strategic differences between those who seek to train leaders for ethnic communities in situations of underdevelopment, regardless of the external "professional" value of their educational credentials, and those who want to close the gap between indigenous and non-indigenous students inside universities and to train elites from vulnerable groups, that is, strategic elites for the whole society, with no particular consideration of their social marginality and cultural diversity ${ }^{1}$.

\footnotetext{
1 "The concept of functional elites [] or strategic elites [] share the basic assumption that modern societies were characterized by structural differentiation []: this hierarchical differentiation was seen as a functional necessity and it was posited that the leadership tasks in each subsystem were most efficiently performed if the elites members were recruited on the basis of meritocracy no inheritance. In distinction to the older elites theories, the functional view was democratized in that it insisted on the plurality of sectorial elites and that it did not construct an opposition between elites and masses but, rather, a hierarchical continuum of status position" (Kreckel, 2005, p. 6).
} 
Conflict and fragile agreements are, therefore, central notions for proposing a classification of actions aimed at improving enrollment and graduation rates of young indigenous peoples in higher education, which complements the three typologies most commonly used by specialists and experts.

The first, based on the mechanisms installed to attend indigenous population, distinguishes: a. indigenous universities, generally managed by indigenous intellectuals, offering students an education that would respect their condition of linguistic otherness, recognize their autochthonous background and value their specific forms of learning (collective and experimental more than competitive and individualistic); b. intercultural universities: by favoring the interaction between indigenous and non-indigenous students, they encourage mutual respect and train the students in careers that are relevant to the local job market c. indigenous student application programs to conventional universities (quotas for admission for Amazonian students in San Antonio Abad University in Peru), retention program for underperforming students or facilities support program for graduation; d. B.A. or graduate programs in intercultural education and/or teacher training, aimed at teachers in the native school system, who were previously recruited in an "improvised" way (Nicaragua).

A second classification is based on objectives and strategies. It separates initiatives of an educational nature aimed at students who are at risk in school or psychologically and affirmative action's consisting mostly in proactive procedures and measures for the mitigation of racial discrimination in higher education, the training of indigenous leaders and the increasing of cultural diversity.

A third distinguishes the initiatives that, with aims of ethnic selfempowerment and, occasionally, compensation, provide indigenous persons with specific educational services and those that, with the aim of mainstreaming intercultural capabilities, design alternative programs for the indigenous students in their communities.

Without contradicting these typologies, we propose one that is articulated on the interactions between actors, with a view toward reflecting on the relationships of power that sustain them. We contrast a. participative agreements, with initial and ongoing accords between managing and financing organizations, b. agreements with pre-established norms and evaluation criteria, due to accountability demands, and c. hierarchically organized agreements, with the ascendancy of one group over the others. The degrees of adaptation to the contexts and circumstances and the possibilities of internal adjustments to ensure the viability and efficiency of the agreements vary considerably between these categories but on the principle: the greater the flexibility, the greater the possibilities for guaranteeing their permanence. An example is the Pathways program: financed by the Ford Foundation, it was designed in Brazil, Chile, Mexico and Peru in a decentralized manner, which made possible an institutional appropriation that counterbalanced the unavoidable opposition generated by its application (Didou \& Remedi, 2009). 


\section{Fairness and Social Responsibility: Core Concepts for Institutional Change?}

Due to the inclusion of ethnic-initiatives in two fields of external legitimization of higher education, those of innovation and social responsibility, we will now analyze the organizational tensions caused by the execution of programs focused on indigenous enrollment in conventional HEI, as well as the challenges involved in terms of public policy in the opening of indigenous and intercultural universities.

With regard to programs in conventional universities, the literature indicates that they have an impact on the three substantive functions of public universities. Educational processes are modified by experimentation in teaching methods for the transmission of knowledge, by the design of remedial didactic approaches and by attempts to create an intercultural and plurilingual curriculum. This meant that many HEI had to debate competency profiles of teachers in charge of indigenous students and involve them in training workshops on interculturality, diversity and indigenous populations, teaching strategies, classrooms pedagogy and the preparation of specific tools and syllabus.

In research, the rise of indigenous education was accompanied by the simultaneous emergence or reinforcement of research groups. They produced scientific articles and follow-up evaluations, dissertations and reports on an institutional scale, builded networks to call attention to themselves and to organize their area of specialization (Red de Orientación Académica Latinoamericana) ${ }^{1}$ and launched specialized journals (Cuadernos interculturales in Chile, since $2003^{2}$, Aquí estamos, in Mexico ${ }^{3}$ ).

Cultural extension programs were equally affected to the degree that, in many institutions, social and cultural recognition of the presence of indigenous students led to the staging of music and dance performances, symbolic of their cultural diversity. Young indigenous persons were either proud to show others their culture or questioned the "folklorization" of their identity, mainly when they already belonged to a second generation of urban migrants.

The inclusion of ethnic higher education programs in traditional universities had repercussions in several other spheres of institutional life. It reinforced ties with indigenous communities so that indigenous students could do their internships, social service and thesis fieldwork there. HEI consider this relationship as proof of social responsibility, but the inhabitants do not always see it this way and criticize the absence of constructive proposals for resolving concrete problems. Ethically, it allowed universities to reaffirm their commitment to vulnerable groups and even encouraged the establishment of programs dedicated to persons with disabilities or single mothers, transferring the competencies regarding indigenous peoples to other population groups in a similar social condition of fragility/marginality. Normatively, it led some

\footnotetext{
${ }^{1}$ Orientación Académica Latinoamericana [Latin American Network of Academic Guidance]. http://roal.fundacion-equitas.org/.

${ }^{2}$ Cuadernos interculturales [Intercultural Journals]. http://cuadernosinterculturales.uv.cl/.

${ }^{3}$ Aquí estamos [Here we are]. http://ford.ciesas.edu.mx/Revistas.htm.
} 
institutions to include in their regulations precepts regarding positive discriminatory or affirmative actions. Organizationally, it made them open specialized offices for managing the program, providing attention to indigenous students and handling relations with other departments (school services, student medical attention). Some HEI's included in their questionnaires for first-year students questions regarding ethnic origin through different sets of indicators (self-identification, origin of parents, native language) and generated data about their situation and needs.

The changes obtained, although undeniable, were often circumstantial and temporary. Their permanence depended on the continuation of the programs that financed them. For instance, only 12 of the 24 universities in Mexico that participated in Pathways maintained the established structures when the resources ended (ANUIES, 2012). The discontinuity of the processes was due to institutional arbitration in the assignation of resources (which showed the random nature of the actions aimed at indigenous peoples) and the objections addressed by university actors and indigenous or students associations at the initiative. In external and internal environments where those programs go against an internal climate in traditional universities marked by discriminatory attitudes toward indigenous peoples, their institutionalization becomes a crucial issue for triggering profound changes beyond political opportunism.

Intercultural or indigenous universities faced dysfunctions similar to those previously described; for instance, with regard to the roles of local communities, ethnic organizations and students in institutional decision making. Indigenous local authorities donated land and even offering free work to build intercultural or indigenous universities and maintain the installations. They supported students who had to migrate for educational reasons, offering them help for meals and lodging through grants, dining halls and residences managed by community representatives or self-administered by indigenous students. However, they frequently voiced displeasure with regard to the usefulness of the knowledge generated by students to solve the everyday problems of their communities, even arguing that the fieldwork done by students was not suitable for their purposes; projects for supposedly "applied" research, according to this view, were defined less as a response to their demand than a result of institutional priorities or a product of the interests of the tutor. In this sense, successful collaborative practices between university students and indigenous peoples should be disseminated in order to improve connections between their respective agendas on strategic questions for both parties.

Beyond their ties with ethnic organizations from target population groups, indigenous and intercultural universities face other problematic scenarios. One of them is promoting equity with a view toward recognition of diversity: it means attracting a greater number of indigenous students and insuring that they acquire significant knowledge, both professionally and socially. Some followup studies of the first graduates indicate difficulties in gaining access to the formal job market, except in sectors traditionally associated with teaching and with attention to indigenous populations. Although statistics are still 
inconclusive, they indicate that job opportunities for indigenous graduates from conventional universities are better than for graduates from indigenous or intercultural institutions. The attainment of a graduate degree, mainly a $\mathrm{PhD}$ from a foreign institution, has a positive impact on their employability. In addition, the higher the level of education (mainly at doctorate level), the greater the opportunities for successful self-employment, for example, obtaining resources to create an NGO. Another problematic aspect has to do with quality assurance: in the last 20 years, Latin America consolidated evaluation and accreditation systems for conventional universities. The indicators used are not applicable to recently created institutions, which attract mostly students with a different educational and social capital.

This review shows that the conflicts that revolve around ethnic-type programs/institutions are not produced exclusively by the definition of basic agreements with regard to the projects, but rather emerge from implementation processes. They are evident on two levels. The first is that of university organization, when innovative initiatives lead to changes in traditional schemes of functioning in conventional universities. The second is the absence of evaluation mechanisms that would be able to demonstrate the quality of the training provided.

Additionally, a third topic, on which we cannot expand due to the lack of reliable information, is the return of indigenous professionals to their communities and the kind of social activism they exercise. Recent research indicates that the organization of the Continental Campaign 500 Years of Indigenous, Black and Popular Resistance in opposition to the 500th Anniversary of the Discovery of America produced a generational and educational change of guard in ethnic leadership, for instance in Mexico ${ }^{1}$. Discussion about how and where to begin defining indigenous intellectuals, professionals and leaders is today the subject of articles and books in several countries, generated in part by indigenous peoples themselves (Simon, 2009 in Bolivia; Flores, 2011 in Ecuador).

Nevertheless, a problematic point involves indigenous professionals: in the interviews we had with 22 of them in Mexico, as well as in their official biographies or personal life stories; they mention that they suffer discrimination not only due to ethnic racism, but also poverty and gender. In addition, the latter is aggravated when the professional indigenous women return to their communities, because of uses and customs that limit their possibilities of exercising leadership or professional roles and representative functions at political level.

\footnotetext{
1 "During recent Indian struggles new intellectuals have been appearing, several of them young graduates from centers of higher education, a situation which has also made indigenous peoples seek the training of new leaders and intellectuals and even to build their own centers for the training of intellectuals, such as intercultural schools and universities, supported by the will of collectives" (Flores, 2009, p. 193)
} 


\section{Internationalization: Contributions and Criticisms}

The third core concept of our reflections involves internationalization. In all of Latin America, investments from international organizations have been decisive in consolidating the field of ethnic higher education and including the matter of a global agenda on human and civil rights (Flores, 2005). Their participation has been responsive (to different types of petitions and proposalsgovernmental, institutional and associational) or proactive (through public convocations), depending on their work programs and priorities (Didou, 2013). They mainly consisted of:

- Scholarships to study for a university degree in the country or for longterm or short-term international mobility. Between 2001 and 2010, the Ford Foundation awarded scholarships to 1,017 indigenous students from Brazil, Chile, Guatemala, Mexico and Peru for graduate studies in their countries or abroad: $42 \%$ of them studied in their country, the remaining percentage abroad, but in Latin America (Dassin, 2014).

- Access, retention and graduation programs for indigenous students, in undergraduate and graduate levels.

- Institutional consolidation of intercultural and indigenous universities.

- Reinforcement of research capabilities on indigenous matters: in the areas of health, language and agronomy, they supported the recuperation of autochthonous knowledge and opening research centers.

- Formation of networks to discuss operational issues in the management of affirmative programs, carry out research or connect graduates.

- Hiring experts to track, accompany and evaluate programs.

- Collection and preservation of historical archives.

- Scientific and diffusion publications in books and magazines.

In turn, the predominant participation of international organizations generated questions with regard to their legitimacy as decisive actors in ethnic higher education, in the articulation of interests between donors and grantees, in their responsibility in the migration of widely used concepts for the consolidation of native higher education (interculturality, for instance) and in their investments to promote the adoption of actions or formulas that contradict indigenous views.

With regard to equity, the principal doubts have to do with the adoption of special ways of admittance or quotas programs as ad hoc instruments of intervention to "empower" young indigenous people. In the area of diversity, groups of indigenous intellectuals strongly criticized the presence of international organizations in the field of indigenous higher education, the contents of theirs programs and their general objectives. They justified their arguments by turning toward essentialist conceptions of an indigenous identity in conflict with those of the "others" (Dietz, 1999, p. 3). They issued political criticisms against neo-colonialism insofar as it is a constituent feature of modernity promoted by international organizations. Postulating ethnogenesis as 
a process for the constitution, formation and preservation of a cultural group defined by characteristics that are different from those of other groups, they believed that international organizations represented a direct threat to their identity, unless their intervention were limited by the mediation of the indigenous people themselves.

\section{Conclusions}

This review allows us to emphasize that indigenous higher education is plagued with contradictions. Regardless of the doctrinaire or militant speeches made by those who promote it, these contradictions are rooted both in the premises behind the programs and institutions as well as in the wider debates regarding social stratification, cultural diversity and otherness. The foregoing implies that although indigenous higher education represents a core research concept for scholars in the field of education and psychologists (as it relates to active processes of stereotyping and intolerance), it should also be approached from other analytical paradigms of a sociological or political nature. Among these, the most important are those that to do with the generation of disadvantages and poverty, governability and social stability, the formation of elites and processes of selective inclusion of marginalized groups. There is still much to be studied in this regard.

\section{Acknowledgements}

This paper was prepared with the support of the National Council of Science and Technology (Consejo Nacional de Ciencia y Tecnología, abbreviated CONACYT) to the research project num. 152581 on Indigenous higher education in Mexico, coordinated by Sylvie Didou Aupetit. The Spanish version has been translated and edited in English with help of UNESCO Participation Programme 2012-2013 and Mexican National Commission for Cooperation with UNESCO (Comisión Mexicana de Cooperación con la UNESCO, abbreviated CONALMEX) to UNESCO-Chair.

\section{References}

ANUIES/Coordinación Central PAEIIES (2012). Programa de apoyo a estudiantes indígenas en Instituciones de Educación Superior: Memoria 11 años de trabajo [Program to support indigenous students in higher education institutions: Report of 11 years of work]. México: ANUIES.

Bello, A. (2004). Etnicidad y ciudadanía en América Latina. La acción colectiva de los pueblos indígenas [Ethnicity and Citizenship in Latin America. The collective action of indigenous people]. Santiago de Chile: CEPAL, United Nations Publishers. Retrieved from http://bit.ly/1VECpBG.

Bengoa, J. (2003). Relaciones y arreglos políticos y jurídicos entre los estados y los 
pueblos indígenas en América Latina en la última década [Political and legal relations and arrangements between states and indigenous people in Latin America in the last decade]. (Serie Políticas Sociales n. 69). Santiago de Chile: CEPAL, United Nations Publishers. Retrieved from http://bit.ly/1CU62ZX.

Chojoj Mux, J. (2012). Políticas de educación superior y pueblos indígenas (maya, xinca y garífuna) en Guatemala [Higher education policies and indigenous peoples (Maya, Xinca and Garifuna) in Guatemala]. In Mato Daniel, Educación superior y pueblos indígenas y afro-descendientes en América Latina. Normas, políticas y prácticas (pp. 245-274). Venezuela: UNESCO-IESALC, Retrieved from http://bit.ly/1SFM2vD.

Cohen, M. D., March, J. G. \& Olsen, J. P. (1972). A Garbage Can Model of Organizational Choice. Administrative Science Quarterly. 17(1) (Mar. 1972), 125. Retrieved from http://bit.ly/1Ko5dIA.

Dassin, J. (2014). Mobility and Equity in Higher Education: The Latin American Experience of Ford Foundation International Fellowships Program. In Sylvie Didou Aupetit (coord.), Los programas de educación superior indígena en América Latina y en México: componentes tradicionales y emergentes (género e internacionalización). México, Venezuela: IESALC-CONALMEX-Cátedra UNESCO.

Didou, S. (2013). Cooperación internacional y educación superior indígena en América Latina: constitución de un campo de acción [International cooperation and indigenous higher education in Latin America: establishment of a scope]. Revista Iberoamericana de Educación Superior, 4(11), 83-99. Retrieved from http://bit.ly/1LALfgP.

Didou, S. \& Remedi, E. (2009). Los olvidados: acción afirmativa de base étnica e instituciones de educación superior en América Latina [The Forgotten: ethnicbased affirmative action and institutions of higher education in Latin America]. México: Juan Pablos Editores/CINVESTAV-IPN.

Dietz, G. \& Mateos, L. S. (2011). Interculturalidad y educación intercultural en México. Un análisis de los discursos nacionales e internacionales en su impacto en los modelos educativos mexicanos [Multiculturalism and intercultural education in Mexico. An analysis of national and international discourses on its impact on the Mexican educational models]. México: Secretaría de Educación Pública. Retrieved from http://bit.ly/1ImoD0M.

Dietz, G. (1999). Etnicidad y cultura en movimiento. Desafíos teóricos para el estudio de los movimientos étnicos [Ethnicity and culture in motion. Theoretical challenges for the study of ethnic movements]. Nueva antropología, 56, 81-107. Retrieved from http://bit.ly/1ImoGdc.

Essed, P. (2005). Racisme et préférence pour l'identique: du clonage culturel dans la vie quotidienne [Racism and preference for the identical: cultural cloning in everyday life]. Actuel Marx, 2(38), 103-118.

Flores, A. (2011). Intelectuales indígenas ecuatorianos y sistema educativo formal: entre la reproducción y la resistencia [Ecuadorian indigenous intellectual and formal education system: between reproduction and resistance]. Revista ISEES, 9 (jul-dec 2011), 21-39. Retrieved from http://bit.ly/1Mrwqxg.

Flores, J. J. (2009). Las luchas indias y sus intelectuales [Indian struggles and their intelectual]. Veredas, 10(18), 193-213. Retrieved from http://bit.ly/1Mp4pW3.

Flores, J. J. (2005). De indios integrados a sujetos políticos [Indian integrated political subjects]. Argumentos 49, 69-90. Retrieved from http://bit.ly/1MMgxyj.

Kreckel, R. (2005). Education, knowledge and social differentiation: new elites and new inequalities? 7th Congress of European Sociological Area, Rethinking 
inequalities, Poland, September 10-13.

López, L. E., Moya, R. \& Hamel, R. E. (2009). Pueblos indígenas y educación superior en América Latina y el Caribe [Indigenous peoples and higher education in Latin America and the Caribbean]. In L.E López, (Eds.), Interculturalidad, educación y ciudadanía: perspectivas latino-americanas (pp. 221-289). Bolivia: PROEIB Andes. Retrieved from http://bit.ly/1gSbhzj

Simón, J. D. (2009). Los intelectuales indígenas y la formación de talentos humanos para un mejor y buen gobierno [Indigenous intellectuals and the development of human talents for better and good governance]. El vuelo de la Luciérnaga 3, 112137. Retrieved from http://bit.ly/1elCFUh.

Zapata, C. (2009). Indígenas y educación superior en América Latina: los casos de Ecuador, Bolivia y Chile [Indigenous and higher education in Latin America: the cases of Ecuador, Bolivia and Chile]. Revista ISEES, 9 (jul-dec 2011), 71-101. Retrieved from http://bit.ly/1Mrwqxg. 